\title{
KINGA VAJDA* \\ OPPORTUNITIES AND SPECIFICS UNDERLYING DAY CARE FOR OLDER ADULTS IN HUNGARY WITH CONSIDERATION OF ACTIVE AGEING
}

(Received: 11 August 2019; accepted: 1 March 2020)

In the past few decades, ageing has become a serious global issue. The concept of active aging and its incorporation into different type of social services (e.g. day care for elderly people) is one of the possible solutions. The main goal of this research was to evaluate the status of clients in Hungarian day care institutions. Another important goal is to explore which domains of the concept of active and independent ageing were already considered and applied in Hungarian day care service and where they should be strengthened. The questionnaire was based on the Active Ageing Index questionnaire (ZAIDI et al. 2013). 14\% of the observed sample was 64 years old or younger, $38 \%$ was $65-74$ years old, $36 \%$ was $75-84$ years old, $12 \%$ was 85 years old or older. Most of the participants (74\%) were women. More than half of the sample were widowed. One third of the sample received some kind of ICT (Information and Communication Technology) device. There was a strong connection between the frequency of ICT usage and education variables. Accessibility, which was also a facilitator of active and independent ageing, came up only in $25 \%$ of the sample. Mental well-being - as a new variable - was analyzed with principle component analysis from five former variables with the highest rate in the Central Hungarian region. Satisfying physical security was reported by only $56 \%$ of the sample, more often among men (p $=0.03$ ). Reinforcing the preventive aspect of the service, propagating it amongst freshly retired people, and including not only widows, but other potential clients as well could be the key points of service development. To intensify the potential points in the service connected to active ageing (accessibility, volunteering in late-life, use of ICT devices etc.) could be a key factor in the improvement of day care services.

Keywords: demographic change, ageing, community based social services, active ageing, day care for elderly people

* Kinga Vajda, Semmelweis University, Dr. Károly Rácz School of PhD Studies, H-1428 Budapest, PObox 2., Hungary; kinga.vajda88@gmail.com. 


\section{Background of the topic}

During the last couple of decades, ageing has become a global question. Statistics related to ageing are far from being unified. While the United Nations and the WHO (World Health Organization2018) are currently issuing statistics about the population over 60, several EU countries, including Hungary, report age-related issues for people over 65 years of age (SPÉDER 2019). According to the United Nations (2017) 962 million people lived in the world aged 60 or over, which represented $13 \%$ of the global population. Based on the most relevant statistical data, the number of people aged 60 or above in a society is expected to rise from $12 \%$ to $22 \%$ around the globe (World Health Organization 2017). In the EU, where societies are typically considered as ageing ones, the proportion of people aged 65 or above will increase from $19.2 \%$ to $29.1 \%$ between 2016 and 2080 (Eurostat 2017). It is also remarkable that the oldest age group ( 80 or older) will grow from $5.4 \%$ to $12.7 \%$ during the same period. Eurostat estimates that in $2080,63.8$ million citizens aged 80 or older will be living in the European Union ${ }^{1}$.

These changes will strongly affect the current economic, social, and health systems, and major transformations will be needed to achieve sustainability and improve the quality of care.

\section{Active Ageing as a possible answer for changing demographic trends - definition and measurement}

Countries that recognized societal aging as a social problem tried to find solutions individually for the increasingly intensive, multi-sectoral changes. They made efforts to deal with ageing as a multi-dimensional problem, which cannot be solved by simple actions and one-dimensional solutions, such as raising the retirement age. According to the WHO: 'Active ageing is the process of optimizing opportunities for health, participation, and security in order to enhance the quality of life as people age' (World Health Organization 2014, 12). This definition also shows the multidisciplinary approach of active ageing. Definitions, and even the notions used in the definitions are not unified, while the term 'active ageing' is the most widespread in Europe, 'successful ageing' is more commonly used in the United States (CONSTANÇA et al. 2012). Active ageing generated the appearance of new concepts, such as the 'silver economy' (KLIMCZUK 2016, ZSARNÓCZKY 2016). There have been slow changes occurring in the past two decades, where every key actor in social policy: citizens, governments, economic actors and also NGOs have been increasingly recognizing the importance of active ageing, considering it, and rethinking the development of the services (WALKER \& MALTBY 2012). Integrating the active ageing concept into social policy and trying to find the parallel lines between the active ageing concept and the actual social services could be a good answer for the problem of ageing in modern

1 http://www.publicpolicyexchange.co.uk/media/events/flyers/IK08-PPE2_flyer.pdf. 
societies. Besides pressure reduction, promoting active ageing through communitybased social services could be efficient as a preventive approach postponing the need for long-term care.

Connected to the measurement of ageing, it is obvious, that traditional demographic indicators are not capable to calculate and demonstrate the acceleration of ageing and the economical, health, and social consequences of that process (VARGHA 2017). As active ageing became an accepted concept, the need to make it measurable gained traction. Active Ageing Index (AAI) (ZAIDI et al. 2013) is a complex indicator that shows a more accurate picture, and calculates with ageing as a process, although it has been criticized several times since its creation (DE SÃo JosÉ et al. 2017, KARPINSKA \& DYKSTRA 2015).

\section{Empowering community-based social services, basic social services, and the importance of prevention}

Considering active aging concepts seems like a logical choice to empower and support community-based social services (including basic social services for older adults from Hungarian Social Act 1993: 1993. évi III. törvény a szociális igazgatásról és szociális ellátásokról). The basic idea behind empowering community-based social services is that older adults who are still living in their own homes receive social services from community-based social services. Consequently, they would only have to move from their usual environment when it is inevitable, for instance, if the need for high care arose (VAN EENOO et al. 2016).

Receiving community-based social services can be useful from various aspects. First of all, for older adults, adaptation to a new environment is a difficult task. Moving to an unknown location (such as nursing homes) is considered as a significant life event, which is difficult to tolerate by the elderly (JOHNSON et al. 2010; LEE et al. 2013). Furthermore, the quality of life can even change when the 'new' home makes efforts to make the social and physical environment resemble the previous one, or the so-called 'home' (FALK et al. 2013).

Research has shown that depression, dementia, and anxiety disorders are more common among clients appearing in long-term care (especially in institutionalized long-term care), and these symptoms frequently lead to other illnesses (SEITZ et al. 2010). It also confirms, that ageing in place (like home care or day care service) is probably a good solution for elderly care. It is also essential to mention that long-term care is more expensive (CHAPPEL et al. 2004).

As a result of the economic crisis, European social care systems began to empower community-based social services. Some sort of 'shift' has been experienced in welfare services. This included the partial privatization of certain benefits, some kind of vertical subordination, where the responsibility of the care has moved between governmental actors, e.g., tasks have been transferred from the central to municipal governments or directly to the caregivers in informal care. In order to 
control the impact of these changes, a group called COST Action IS1 $102^{2}$ has been formed. The aim of this group is to make impact assessments as a result of the transition system (DEUSDAD et al. 2016). Further to its controlling function, this can also serve as an independent feedback system for service providers.

There are several good practices to promote active ageing according to community based services and the literature (JAWOR-JONIEWICZ et al. 2013; FRERICHS et al. 2012). In many cases, they have been developed and used in the framework of a temporary project, unfortunately, a significant part of them was not tested or was stopped shortly after the project was closed. Many excellent ideas have been implemented in the form of a project with the support of the Active Assisted Living Programme, cofinanced by the European Commission. One example is the ACCESS project (2013) which makes elderly home care more flexible with the help of ICT. ALICE project $(2010)^{4}$ also uses ICT to keep social connections alive for older adults who remained in their homes, and who are capable of maintaining their quality of life with the help of the project. ActGo-Gate $(2014)^{5}$ connects older adults in need of voluntary help and host organizations or older adults who are willing to volunteer through a direct web interface.

The new ideas are increasingly considering not only the elderly, but also the other generations surrounding them. a good example of this is the CAS project (CAS - Centrum Aktywności Seniora alternatywą na samotność) introduced in a disadvantaged region of Poland. In addition to the so-called 'usual' activities and connections, the project put a strong emphasis on addressing the younger generations and getting them involved in programs, e.g. by creating a TV programme about the elderly generation, aimed directly at the younger generation. As a result of the joint programs, the attitudes towards the elderly people and ageing have changed, and the elderly have also been involved in the everyday life of the community (RYNKOWSKA \& BŁASZCZUK 2014).

Overall, it can provide positive results if the clients can stay in their own homes until they can manage their daily activities independently or with occasional support. If it will be possible with the help and implementation of active ageing into social services, then providers will have to build in new approaches and good practices into their operation. Local or international good practices, new programs, and technical solutions can help to this age group to live independently for as long as possible. Implementation of good practices and new solutions are in the interest of all participants. Active ageing and social care would be more effective if policy makers paid more attention to prevention and started to prepare younger generations to ageing by changing their attitude.

2 Retreieved 1 May 2020 http://www.cost.eu/COST_Actions/isch/IS1102.

Retrieved 25 Jan 2019 from http://www.aal-europe.eu/projects/access/.

Retrieved 1 March 2019 from http://www.aal-europe.eu/projects/alice/.

Retrieved 1 March 2019 from: http://www.aal-europe.eu/projects/acto-gate/. 


\section{Research, results}

\subsection{Aim of the research}

The main goal of the research was assessing the situation of day care for older adults (also known as elderly clubs) and care recipients in Hungary. The research focused on the strengths and weaknesses of day care to create an accurate picture of the analyzed elderly group and observe its characteristics involving a wide spectrum of variables partly connected to active ageing. Another area to be explored was the proportion of active ageing domains in the service recipients' life? It is also important to analyze the points where it is possible to improve day care for elderly people. It is essential to know what specific fields need to improve to keep on participating in society and maintain social connections for the elderly, and what fields need to be developed in the future to support active and independent ageing (VAJDA 2017).

\subsection{Methodology, measurement tool}

The Active Ageing Index (AAI) questionnaire (ZAIDI et al. 2013) gives the basis for the measurement tool used in this research. The AAI questionnaire was compiled using questionnaires of previous European Union surveys, including questions from the European Social Survey (2008; 2010; 2012), the European Labour Force Survey (2008-2012), the European Quality Of Life Survey (2011/2012), the European Statistics of Income and Living Conditions (2008-2012), and the Eurostat ICT Survey (2008-2012). The European Health and Life Expectancy Information System (20082012) was also used to calculate the final index numbers for countries. Besides the strong methodological background and the effective comparison numbers between countries, there are different types of weaknesses of the index, which will be discussed later. Selecting the AAI questions, the 4 domains that involve the indicators/questions were crucial. These 4 domains were the following: employment; social participation; independent healthy and secure living; capacity to maintain an environment for active ageing. With this determination of active ageing, a hardly defined concept became more understandable and tangible. After its development, the methodology of AAI has been used by several researches with varying results (FANTA 2018; BARYSHEVA et al. 2018; GUNTUPALLI \& CHAKRABORTY 2018). There are critical points and arguments against the complete adaptation of AAI:

- Comparing smaller territorial units, e.g. regions, counties, there is a difficulty of using some variables due to the lack of necessary territorial statistical data (Perek-Bialas \& Mysinska 2013).

- The validity of using the same weight for every country was also questioned, knowing they have completely different historical, economic, and service systems. The aggregation of the results and statistics of completely different surveys for index calculation has raised further questions about the reliability of the results (ATKINSON \& MARLIER 2012). 
- The importance of spirituality and religiosity has also been highlighted by earlier AAI researches (AMADO et al. 2016). These questions were not part of the original AAI questionnaire.

- Observation of accessibility was extremely important, as this option makes it easier for an older adult to stay in their own home. This contributes significantly to active, independent ageing.

A good example for a different point of methodology was a diversity research made in a Spanish region (Galicia). They obtained data for the 4 domains from interviews, not from statistical datasets or questionnaires like the AAI did. They called it 'individual adaptation to active ageing index'. Based on the comparison of the active ageing index and the individual adaptation to active ageing index, the results calculated from the interviews in 2 (employment, social participation) out of the 4 domains was almost the same as in the original index, in the other 2 domains, data showed striking resemblance. All of this suggests that qualitative methods can be used to calculate the active ageing index, it can be a tool used quickly by individuals, and can be efficiently used on a personal level (PIÑEIRO VÁZQUEZ et al. 2018).

Despite the criticism, the questionnaire applied in this research was chosen because it offered a new viewpoint, and with a slight addition, it contained all important fields that had robust impact on active ageing. During designing the measurement tool for data collection, a lot of emphasis was put on creating a revised, useful questionnaire, with retaining the main domains of the index. However, it was inevitable to implement changes. The original version of the index applied to age groups of 55 years or older, the Hungarian research mostly involved 65people aged 65 or above. Certain questions were thus less adequate due to the typically higher age of the sample or the special nature of the Hungarian group observed, e.g. economic activation in the group of retired people, which number was particularly low in Hungary (in 65-74years-olds the proportion of economically active people was as low as $4.2 \%$ ) (Eurostat 2016). The aim was not to create a single index number; the existing questionnaire was rather used as a well-established thematic framework, which was adapted to the characteristics of the Hungarian sample. In this research, a questionnaire consisting of 35 questions and based on the original AAI questionnaire was created and applied.

Instead of questions about the proportion of economic activity in this age group, two other questions were involved, which were not part of the original AAI questionnaire. These two questions were also part of the EU-Labour Force Survey (EU-LFS), but the organizers of the index did not include them. The selected questions concerned with the respondents' income-generating activities and non-income generating activities (e.g., domestic work) and provided more valuable information about the target group.

In addition, two more question groups were included in the questionnaire, because of their relation to active, stable and independent ageing:

- accessibility in residential property

- religiosity 


\subsection{Sample}

Out of the six community-based social services ${ }^{6}$ currently available for older people in Hungary, day care was selected for the study. As residents of day care institutions, clients take part in programs focusing on socialization, and in different cultural and leisure programs. This service provides daytime activity for older people, usually supplemented with social catering (1 hot meal/day). Providing health monitoring programs and mental well-being guidance are also primary aims of day care. Professionals are capable of monitoring clients and are able to follow occurrent changes in their physical and mental status. Care needs are mostly not essential for clients in day care, although it is part of the service elements that the Social and Family Affairs Regula$\operatorname{tion}^{7}$ mentioned. If care needs increasing, clients can take domestic care instead of the day care service. The primary reason why this service was selected over other community-based social services is that the characteristics of active ageing are most likely to appear in those elderly groups that are more or less able to take care for themselves, living in their own, well-known places. They are the ones who need daily or occasional service in day care, so they already appear in the social system, yet they live their days actively and independently without increased care need. According to the relevant data of the Hungarian Central Statistical Office (STADAT, Social Statistical Yearbook), the service of day care for older adults was used by 31,249 people who were 65 or older in 2017 (Központi Statisztikai Hivatal 2018). As per the statistics, the geographical distribution of service users shows an uneven pattern.

Data collection for this research was made between the end of 2016 and the first half of 2017. Following the well-run pilot survey, the questionnaire sent to regional centers (institutions) providing day care for older adults as a self-completed, anonymous questionnaire for clients. Convenience sampling was used as a sampling method, every day care service user in the regional centers' institutions had a chance to become part of the sample. 397 people participated in this survey and filled the questionnaire.

\subsubsection{Regional affiliation}

According to national statistics, the larger the region, the more elderly adults live there (Központi Statisztikai Hivatal 2013), except for Southern Transdanubia and Central Hungary. The highest response rate in the research was found in Northern Hungary, while the lowest was found in Western Transdanubia (Figure 1). Although Central Hungary has a remarkable number of elderly population, with $10 \%$ of the participants, they were only the fifth in the line in terms of the number of regional participants. 31\% of respondents live in the Western, and 59\% live in Eastern regions, complemented by $10 \%$ in Central Hungary.

6 Social catering, domestic care, day care, alarm system based home assistant, family support service, village and home stead caretaker service

7 I/2000 Social and Family Affairs Regulation about the professional responsibilities of the social care institutions providing personal care and the conditions under they operate 


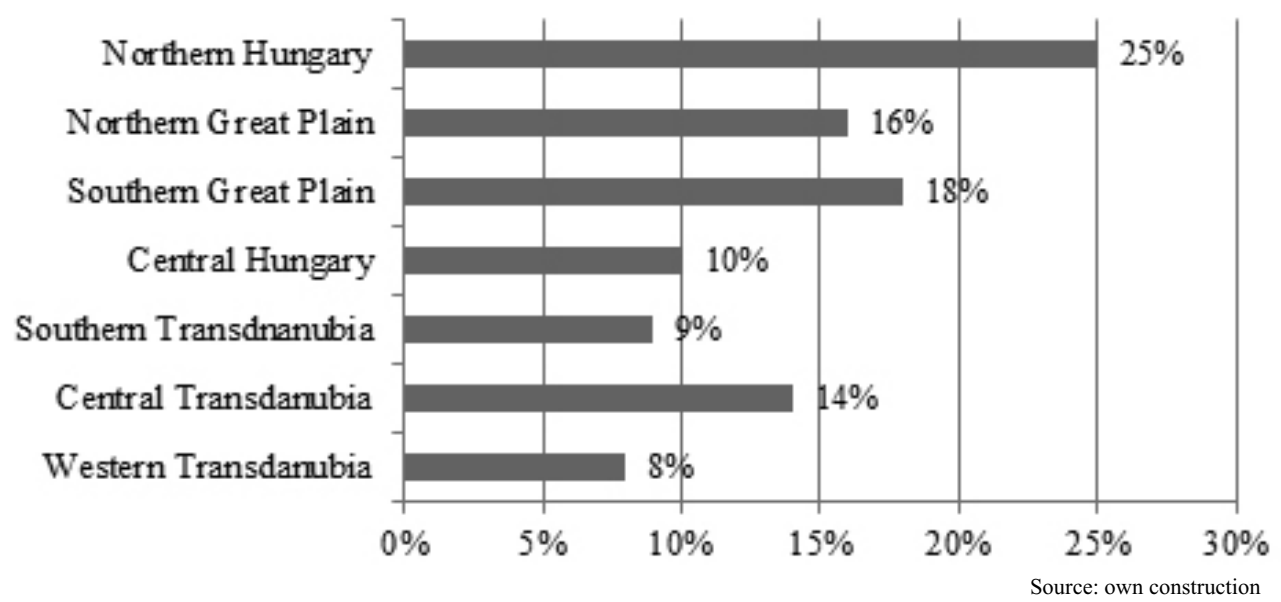

Figure 1

Percentage of respondents in the regions $(\mathrm{N}=397)$

\subsubsection{Distribution by gender}

Three-quarters of the respondents were women, while only $26 \%$ were men. This ratio corresponds to the gender distribution of the national sample for elderly day care recipients (38 551 people, $72 \%$ women and 28\% men, Központi Statisztikai Hivatal 2017). In most community-based social services, women are so overrepresented that it cannot be explained only by higher life expectancy. It is more likely that they are more willing to receive benefits and services and more likely to seek help than their male counterparts.

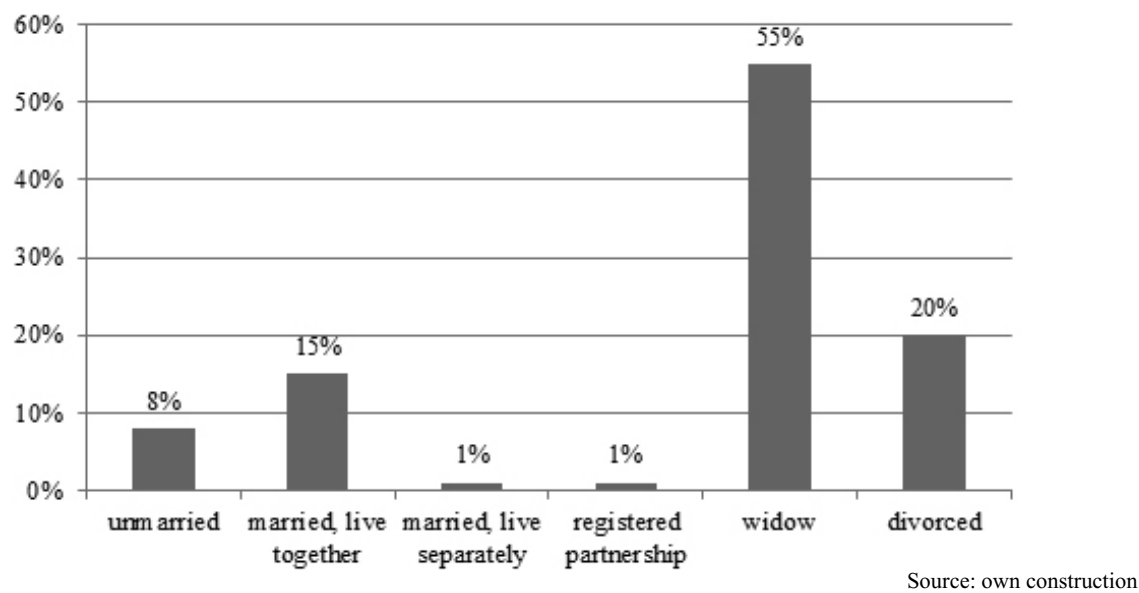

Figure 2

Respondents' marital status $(\mathrm{N}=394)$ 
In the sample, widowed participants appear in the highest proportion (55\%), while divorced ones follow them with $20 \%$. This shows that day care service reaches mostly the group of people who live alone or who lost their spouse.

\subsubsection{Distribution by age}

In the sample, the respondents were divided into 4 larger groups according to their age for easier transparency (Table 1).

Table 1

Distribution of respondents by age group $(\mathrm{N}=390)$

\begin{tabular}{cc}
\hline Age groups & Percentage \\
\hline 64 or younger & $14 \%$ \\
$65-74$ years old & $38 \%$ \\
$75-84$ years old & $36 \%$ \\
85 or older & $12 \%$ \\
\hline
\end{tabular}

Source: own construction

The so-called 'early old age' (65-74 years) and 'late old age' (75-84 years) showed up in the highest proportion. People aged 85 or over made up $12 \%$ of the sample.

\subsubsection{Education}

The majority of the sample (25\%) graduated from civil schools (today's equivalent would be primary school certification). They were followed by those who graduated from vocational schools $(21 \%)$ and secondary schools $(20 \%)$. Only $15 \%$ of the respondents have a degree from higher education. Education is one of the most powerful explanatory variables in researches, mainly because of its permanence.

\subsection{Results}

\subsubsection{Accessibility}

Only $25 \%$ of the respondents made some kind of accessibility transformation in one or more rooms. Where this transformation happened, it concerned mainly the household's bathroom/restroom; and after that, they focused on the living room or bedroom, then the participants made accessibility changes in their kitchen. Most of the respondents who made their apartments accessible belong to age group 65-74. Regional affiliation did not correlate with accessibility; there is no connection 
between them. Before the analysis, it was assumed that due to the impact of the capital and it is technical development, accessibility is more common in the Central Hungarian region (where the capital is located), but it has not been proved. Accessibility does not correlate with the income situation of the respondents' households $(r=0.091)$ (based on their own subjective judgment) and we only found a weak positive relationship between accessibility and health hindrance $(\mathrm{r}=0.134)$.

\subsubsection{Physical security in the living environment}

The existence of physical security strongly contributes to the activity and mobility of the elderly. Beyond physical mobility, a sense of security is also essential for older people when leaving their home environment for an outdoor program or gathering in the evening. It affects and helps to stay mobile, active, and take part in different meetings no matter how long they last. The safety of the residential area showed a 50-50 distribution. $56 \%$ of the respondents felt that they are not or not at all safe in their neighborhood after dark, whereas $46 \%$ of them said that their living environment was safe or rather safe. In terms of genders, there was a significant difference $(p=0.03)$ whether someone considered their living environment safe after dark. Women reported a lower sense of security. There was no correlation between age and physical security, but there was a link between health hindrance (disease, mental problem, disability in everyday life) and the sense of physical security in the examined sample.

\subsubsection{Dispose of physical goods, especially with ICT (info communication) devices}

Physical goods and objects can influence and facilitate everyday life, and thus affect the quality of life, too. By physical goods, we do not only mean luxury items, but also vehicles (that facilitating mobility) or ICT tools that strongly support communication, e.g. computer, internet, telephone, or tablet. The vehicle helps maintain relationships with people where public transportation is less feasible due to their physical conditions. It can also facilitate other activities that have an impact on long-term independence, such as access to shopping, administration duties, medical visits, etc. $18 \%$ of the sample had a car in their household, while $35 \%$ did not have this option due to financial reasons, and $47 \%$ had no car for other reasons, such as the poor health of the respondent. Older people are extremely vulnerable to loneliness and social isolation; an entire range of studies deal with the concept and the negative effects of loneliness in older life (SINGH \& MisRa 2009; Wong et al. 2017).

A strong connection between loneliness, depression, and other health problems was shown. Some researchers believe that they find the antidote of loneliness in elderly life with the support of religion, spirituality, and creative activities (KUMARI 2015). Probably all these suppositions offer solutions for older adults against loneliness, and what they choose only depends on their nature and needs. Nevertheless, it 
is surely a fact that the different type of ICT tools and learning their use makes it easier for older adults to stay connected with their relatives, friends, and service providers. a significant amount of good practices is available, which can even bridge the gap between generations (SZÉMAN 2012).

$64 \%$ of the sample still did not have access to a computer or any other ICT device in their household. The result was the same for the internet access question with a $1 \%$ difference. Almost every households with a computer had internet connection. There was no significant correlation between gender and computer or gender and internet access. The financial situation of the household was not a significant factor in this question.

The availability of a computer or internet access variables both had a strong connection with the education variable $(p=0.01, p=0.09)$. The higher your education, the more likely your household has a computer or/and internet access. These two variables also correlate with mental well-being (computer $r=0.18$, internet $r=0.2$ ).

Someone having a computer and internet access in their household did not necessarily mean that the person was using the device. For this reason, another question focused on how often they used the computer and/or the internet? $36 \%$ of the sample reported using a computer, with $23 \%$ using it every day, $7 \%$ switched on the computer at least once a week, and only $6 \%$ said that they were using it less than once a month, $64 \%$ reported not using it at all. The results of the internet usage questions were nearly the same: $35 \%$ had internet connection, $22 \%$ used it daily, $7 \%$ went online at least once a week, $2 \%$ once a month, and $4 \%$ less than once per month. I found it appealing that those who had it are also used these technologies regularly. Another critical question was what the users used the Internet fir, and how did it help them? They were asked a multiple-choice question, and for each activity, they could choose yes/no. The top three activities were: collecting information, communication over the internet, and entertainment (Figure 3).

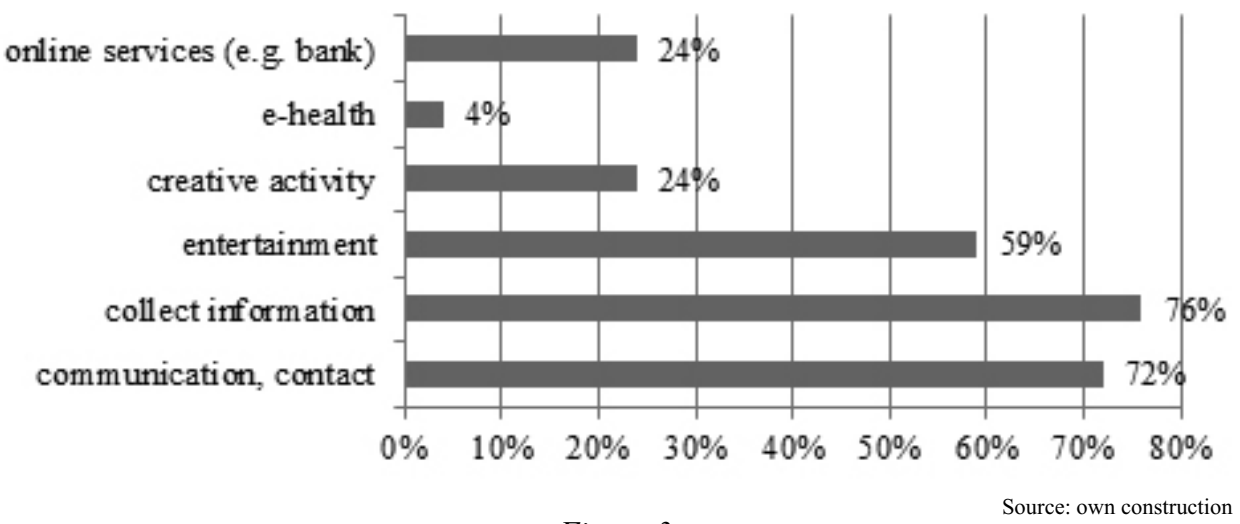

Figure 3

Source: own construction

Activities on the internet among those who has internet connection (multiple choice) 


\subsubsection{The financial conditions of the household}

In the sample, the answers to the question about satisfaction with one's financial conditions were moving in a more neutral direction. Nearly half of the sample, $49 \%$ of the respondents felt that they could manage their household spending; however only $10 \%$ responded that they were satisfied regarding their financial conditions. $23 \%$ said it caused difficulties for them to deal with their financial situation every month, and for $13 \%$, it caused extreme difficulties. Due to the sensitive nature of the question, $6 \%$ did not want to answer. There was a connection between households' financial situation and the level of education $(p=0.004)$, and between financial situation and subjective happiness $(p=0.00)$. This variable correlated with regional affiliation $(r=0.097, p=0.019)$ and education $(r=-0.128, p=0.02)$. In the Western regions of the country, the respondents were more satisfied with the income of their households, the higher someone's education level was, the more satisfaction was reported due to their household's financial conditions.

\subsubsection{Communication as a solution against loneliness}

The number and frequency of confidential relationships have a significant impact on the quality of life not only for older adults, but for all of us. Many types of research highlighted the problem of loneliness and its connection to a range of illnesses in older age. These researches found important relations with variables like health, mental illness, and cognitive abilities (ZHONG et al. 2017; Sin et al. 2018; SмITH \& VICTOR 2018). To avoid reaching an undesired status and to foster active ageing, it is essential to nurture and maintain confidential relationships.

The number of confidential relationships is an accepted concept in social science research, and denotes the number of relationships in which the respondent has the opportunity to share in-depth, private affairs. Those with a strong, stable network of relationships produce more favorable results in terms of physical and psychological variables than their peers (HoRváth-SzABó 2011, DÁvid \& LuKÁCS 2015). According to Hungarian studies, the number of those who do not have confidential relationships is smaller than the international average (ALBERT \& DÁVID 2015). In the 2000s, typically family/relative ties meant confidential relationships, besides them, friendships became increasingly important in the group of confidential relationships (UTASI 2002). According to the recent data, the number of so-called 'chosen confidential relationships', i.e. not with family members or relatives, shows a strong increase, and from 2011, people less frequently reported having confidential relationships with their family members (ALBERT-DÁvID 2015).

In this research, our aim was to investigate the number of confidential relationships based on self-declaration, the personal and other relationships of the respondents with their children (if any), their other relatives, and their neighbors. In the sample, $10 \%$ of the respondents had no confidential relationships at all. This was a low number compared to other groups, but it meant that $10 \%$ of the respondents probably 
could not share their private affairs with anyone, although it could be an important part of independent, active ageing. $21 \%$ of the sample had at least one confidential relationship, $23 \%$ of them had two, $18 \%$ had three and $29 \%$ of them were so lucky that they had 4 confidential relationships. The results showed a positive picture, and community-based social services could be an answer for the $10 \%$ who had no confidential relationships. No differences were found in the number of these relationships according to gender.

\subsubsection{Subjective happiness}

For measuring subjective happiness, a simple but well-functioning question was used. Participants had to provide their answers for the following question: 'Taking all things together, how happy would you say you are?' in a simplified four-point scale. The correlations between the single item (ten-point scale) and both the Oxford Happiness Inventory (OHI; ARGYLE et al. 1995; HiLls \& ARGYLE 1998) and the Satisfaction with Life Scale (DIENER et al. 1985; PAVOT \& DIENER 1993) were significant (ABDEL-KHALEK 2006). This single question about happiness was part of the European Social Survey 2012 questionnaire, too. Using of a single-item question about happiness provides reliable and valid data both in cross-cultural and national studies (ABDEL-KHALEK 2006). 68\% of the respondents identified themselves as 'very happy' or 'more or less happy'. Subjective happiness is one of the most correlating variables. It had a strong connection to the subjective general health status $(\mathrm{r}=0.332)$, the number of confidential relationships $(\mathrm{r}=0.254)$, the financial conditions of the household $(\mathrm{r}=0.210)$ and health hindrance $(\mathrm{r}=-0.209)$. From this sample, it seemed that age, gender, marital status, or education had no significant correlation with happiness.

\subsubsection{Mental well-being as a new variable}

Due to the close movement of the 5 well-being variables included in the active aging index and the questionnaire for this research (variables initially used by the European Quality of Life Survey 2011-2012=EQLS), a new variable was developed with principal component analysis: mental well-being.

The five former variables from the European Quality of Life Survey (EQLS) 2011-2012:

Please indicate for each of the five statements which are closest to how you have been feeling over the last two weeks:

- I have felt cheerful and in good spirits

- I have felt calm and relaxed

- I have felt active and vigorous

- I woke up feeling fresh and rested

- My daily life has been filled with things that interest me

(EQLS 2012) 
While developing the new mental well-being variable, the explained variance was $60 \%$, which meant that the new variable explained the previous 5 variables well. Analyzing the relationship between regional affiliation and mental well-being, it could be said that respondents in Central Hungary, Western Transdanubia, and the Southern Great Plain reached the best results. In contrast, the results of the respondents living in Northern Hungary were the lowest. The new variable had a connection with the subjective happiness variable $(\mathrm{p}=0.00)$ and the household's financial condition $(\mathrm{p}=0.045)$. The built-in subjective happiness variable and the financial conditions of the respondents' households for fixed factors general linear model worked well, especially when age was involved in the model as a covariant. It meant that the two fixed factors with the covariant explained the change of mental well-being at a high level. Age did not affect mental well-being in this sample.

\section{Conclusions}

Statistical data and forecasts predict the unsustainability of social and day care services for older adults in the near future. The rapid increase in the number of elderly people, especially in the oldest group, is an acute problem. Demographic changes and the ageing represent a pivotal problem requiring instant solutions. Due to the increasing inequalities between the needs and the available resources, such as increasing demand, increasing service fees and the lack of human resources, a serious strategic re-planning of the system is needed. It would be necessary to consider the opinions of experts and professionals: to support the improvement of community-based social services for the elderly and recommend the adaptation of the concept of active aging into these services. Preserving the familiar environment and aiding social services in providing help in the clients' own homes are crucial factors of this process. Finding solutions for older adults with special needs, i.e. dementia or other types of disabilities, could be a key factor besides redefining the system of social care, also in respect of improving financial and fringe social benefits for the clients and their informal caregivers. Day care centers could be a good starting point for these changes.

The care for the elderly should be based on the co-operation of the government/ conservators/relatives trio, as it cannot be solved by the partners individually. The observation of the sample clearly showed that there are points requiring urgent interventions. Providing information to the generation about to retire is essential for a preventive approach. Community-based social services, and day care in particular have to be extended not only to women, but also to senior men. In the context of the transformation of the elderly care system, it will be useful to consider that, after changing opportunities and finding new ways, more men can be involved in the system. Besides widows and those living alone, in the future, it will be important to try involving clients with different family statuses. If more people get into social services, different problems and illnesses possibly turn out earlier and can be followed up by professionals. More emphasis should be placed on the involvement of elderly couples into day care services. Improving the use of ICT device skill of the elderly 
seems to be one of the safest, most reliable, and most cost-effective solution that could help older adults in their everyday life. Promoting and supporting accessibility is also essential because, with this, helping older people will be possible in their wellknown environment for a prolonged period. Staying in their well-known place supports staying active and independent longer, while on the other hand, it helps preserve older people's mental health.

While analyzing the data, other observations have been made requiring further studies with different qualitative techniques in the near future:

Utilizing participants' ideas (regardless of their family status) about the possible methods of involving potential clients still living with their spouses. Retired people living with their spouses could also enjoy the benefits of day care services: Active programs, new acquaintances, professional help, and attention can also contribute to the prevention of diseases like dementia.

The goal of using the qualitative interview technique is to get an insight and understanding of the clients' ability to contribute to their own active ageing, helping them to maintain an independent life at their own homes.

In the case of 75-84 years old and 85+ years old people, it seems to be necessary to examine what kind of support could help them best in finding adequate help in day care despite their higher age.

Understanding the differences in preventive methods according to the needs of the different age groups. What do clients and professionals think about the increasing emphasis on prevention in social policies and the appearance of active ageing? Are these concepts suitable to maintain active life during the process of ageing?

My further plan is to complement the results of the quantitative research with the answers for the above-mentioned thoughts using qualitative method. These sets of information could enable us to open new perspectives and find new focus areas for both policy makers and stakeholders regarding the improvement of communitybased, and basic social services for older adults.

\section{References}

1993. évi III. törvény a szociális igazgatásról és szociális ellátásokról [Social Act 1993] retrieved 29 Apr 2020 from: https://net.jogtar.hu/jogszabaly?docid=99300003.tv.

1/2000. (I. 7.) SzCsM rendelet a személyes gondoskodást nyújtó szociális intézmények szakmai feladatairól és müködésük feltételeiről [I/2000 Social and Family Affairs Regulation] retrieved 8 Dec 2019 from https://net.jogtar.hu/jogszabaly? docid=a0000001.scm.

Abdel-KhaleK, A. M. (2006) 'Measuring Happiness with a Single Item Scale', Social Behavior and Personality 34, 139-50 (https://doi.org/10.2224/sbp.2006.34.2.139).

ALBERT, F. \& B. DÁvID (2015) 'A magyarországi kapcsolathálózati struktúrák jellemzői 2015-ben' [Characteristics of Hungary's network structures in 2015], Socio.hu 2016/3 (http://doi. org/10.18030/socio.hu.2016.3.22).

Amado, C.A., J.M. SÃo José \& S.P. SANTos (2016) 'Measuring Active Ageing: A Data Envelopment Analysis Approach', European Journal of Operational Research 255, 207-23 (http:// doi.org/10.1016/j.ejor.2016.04.048). 
Argyle, M., M. Martin \& L. Lu (1995) 'Testing for Stress and Happiness: The Role of Social and Cognitive Factors' in C.D. SpeIlberger \& E.D. SARAson, eds., Stress and Emotion (Washington: Taylor \& Francis) 173-87.

ATKInSON, B. \& E. MARLIER, eds. (2012) Income and Living Conditions in Europe (Luxembourg: Eurostat) (http://doi.org/10.2785/53320).

Barysheva G.A., E.A. Frolova, V.A. Malanina \& E.A. Taran (2018) 'Active Ageing Index: a Russian Study' in ZAIDI et al. (2018) 409-35 (http://doi.org/10.1007/978-981-10-6017-5.

Chappell, N.L., B.H. Dlitt, M.J. Hollander, J.A. Miller \& C. McWilliam (2004) 'Comparative Costs of Home Care and Residential Care', The Gerontologist 44, 389-400 (http://doi. org/10.1093/geront/44.3.389).

Constança P., O. Ribeiro \& L. Teixeira (2012) 'Active Ageing: An Empirical Approach to the WHO Model', Current Gerontology and Geriatrics Research 2012, Article ID 382972 (https://doi.org/10.1155/2012/382972).

DÁvid, B. \& Á. LUKÁCs (2015) 'Kapcsolatok és bizalom az iskolai és családi közösségekben' [Relationships and Trust in School and Family Communities] in A. Falus A., eds., Sokszínü egészségtudatosság: Értsd, csináld, szeresd (Budapest: SpringMed Publisher) 131-40.

DE São José, J.M., V. Timonen, C.A.F. Amado \& S.P. Santos (2017) 'A Critique of the Active Ageing Index', Journal of Aging Studies 40, 49-56 (http://doi.org/10.1016/j.jaging.2017. 01.001).

Deusdad, B.A., C. Pace \& A. Anttonen (2016) 'Facing the Challenges in the Development of Long-Term Care for Older People in Europe in the Context of an Economic Crisis', Journal of Social Service Research 42, 144-50 (http://doi.org/10.1080/01488376.2015.1129013).

Diener, E., R.A. Emmons, R.J. LARSEN \& S. Griffin (1985) 'The Satisfaction with Life Scale', Journal of Personality Assesment 49, 71-75

EQLS (2012) European Quality of Life Survey 2011-2012 Questionnaire, retrieved 1 May 2019 from https://www.eurofound.europa.eu/surveys/european-quality-of-life-surveys/europeanquality-of-life-survey-2012/eqls-2012-questionnaire/eqls-2012-questionnaire-translation.

Eurostat (2016) a Look at the Lives of the Elderly in the EU Today, retrieved 30 Feb 2019 from https://ec.europa.eu/eurostat/cache/infographs/elderly/index.html.

Eurostat (2017) Population Structure and Ageing, retrieved 30 Feb 2019 from https://ec.europa. eu/eurostat/statistics-explained/index.php/Population_structure_and_ageing.

Falk, H., H. WiJK, L.O. Persson \& K. Falk (2013) 'A Sense of Home in Residential Care', Scandinavian Journal of Caring Sciences 27, 999-1009 (http://doi.org/10.1111/scs.12011).

FANTA, J. (2018) 'Quality of Life of the Elderly and Applicability of the Active Ageing Index to Latin American Countries' in ZAIDI et al. (2018) 437-63 (http://doi.org/10.1007/978-98110-6017-5).

Frerichs, F., R. Lindley, P. Aleksandrowicz, B Baldauf \& S. Galloway (2012) 'Active Ageing in Organisations: a Case Study Approach', International Journal of Manpower, 33, 666-84 (https://doi.org/10.1108/01437721211261813).

Guntupalli A.M. \& S. Chakraborty (2018) 'Active Ageing Index (AAI) in India: Is the Approach Used in European Countries Applicable to Developing Countries?' in ZAIDI et al. (2018) 437-63 (https://doi.org/10.1007/978-981-10-6017-5_20).

Hills, P. \& M. ArgYle (1998) 'Positive Moods Derived from Leisure and Their Relation to Happiness and Personality', Personality and Individual Differences 25, 523-35 (https://doi.org/ 10.1016/S0191-8869(98)00082-8).

HoRvÁTH-SzABÓ, K. (2011) 'Kapcsolatok kapcsolati hálóban, Embertárs 9, 4-20

JaWor-Joniewicz, A., J. KorneCKi \& J. WikTORowicz (2013) Catalogue of Good Practices in Relation to Active Aging in Selected Countries of the European Union: Case Studies, carried by Human Resource Development Centre with funds from the European Social Fund, Lodz, 
retrieved 25 July 2019 from https://zielonalinia.gov.pl/upload/50plus/Raport-koncowy/Katalog-dobrych-praktyk-studia-ENG.pdf).

Johnson, R., LL. Popejoy \& M.E. Radina (2010) 'Older Adults Participation in Nursing Home Placement Decisions', Clinical Nursing Research 19, 358-75 (http://doi.org/10.1177/ 1054773810372990).

KARPINSKA, K. \& P. DyKSTRA (2015) Active Ageing and its Extension to the Regional Level: Synthesis Report, retrieved 20 Feb 2019 from https://ec.europa.eu/social/BlobServlet?docId= 13544\&langId=en).

KLIMCZUK, A. (2016) 'Comparative Analysis of National and Regional Models of the Silver Economy in the European Union', International Journal of Ageing and Later Life 10. 31-59 (http://doi.org/10.3384/ijal.1652-8670.15286).

Központi Statisztikai Hivatal (2013) 2011. évi népszámlálás: 3. Országos adatok (Táblák 1.1.2.1), (C) Hungarian Central Statistical Office, retrieved 12 March 2019 from http://www.ksh.hu/ nepszamlalas/tablak_teruleti_00.

Központi Statisztikai Hivatal (2017): Mikrocenzus 2016: 4. Iskolázottsági adatok, (C) Hungarian Central Statistical Office, retrieved 14 March 2019 from http://www.ksh.hu/mikrocenzus 2016/kotet_4_iskolazottsagi_adatok.

Központi Statisztikai Hivatal (2018) Szociális statisztikai évkönyv 2017 [Social Statistical Yearbook 2017], (Budapest: Központi Statisztikai Hivatal).

Kumari, C. (2015) 'Elderly Perception of Loneliness and Ways of Resolving it Through Positive Ageing', Indian Journal of Gerontology 29, 322-30 (http://doi.org/10.4103/0972-6748.57861).

LeE, V.S.P., J. Simpson \& K. Froggatt (2013) 'A Narrative Exploration of Older People's Transitions into Residential Care', Aging \& Mental Health 17, 48-56 (http://doi.org/10.1080/ 13607863.2012.715139).

Seitz, D., N. Purandare \& D. Conn (2010) 'Prevalence of Psychiatric Disorders among Older Adults in Long-Term Care Homes: a Systematic Review', International Psychogeriatrics 22, 1025-39 (http://doi.org/10.1017/S1041610210000608).

SMITH, K.J. \& C. Victor (2019) 'Typologies of Loneliness, Living Alone and Social Isolation, and their Associations with Physical and Mental Health'. Ageing \& Society 39, 1709-30 (http://doi.org/10.1017/S0144686X18000132).

SPÉDER, Zs. (2019) 'Demographic Trends: Fertility, Mortality, Ageing' in: I. Gy. TóTH, ed., Hungarian Social Report (Budapest: TÁRKI) 13-31.

Pavot, W. \& E. Diener (1993) 'Review of the Satisfaction With Life Scale', Psychological Assessment 5, 164-72 (https://doi.org/10.1037/1040-3590.5.2.164).

Perek-Bialas, J. \& E. Mysinska (2014) Regional Active Ageing Index for Poland, retrieved 25 Feb 2019 from http://senior.gov.pl/source/PL_Regional_AAI.pdf).

Piñeiro Vázquez, C., J.M. Méndez Magán, S. Marsillas Rascado, A. Rial Boubeta, T. Braña Tobío \& J. VARela Mallou (2018) 'Study on Active Ageing at Individual Level Based on Active Ageing Index' in ZAIDI et al. (2018) 343-61 (http://doi.org/https://doi.org/10.1007/ 978-981-10-6017-5_20).

RYNKOWSKA, D. \& K. BŁASZCZUK (2014). 'Integration of Senior Citizens for Social Activity' in A. Chabior \& A. Szplit, eds., Ageing and Old Age as a Task (Kraków: Wydawnictwo Libron) $157-75$.

Sin, E.L., H.L. Liu, S.H. Lee, C.M. Huang, Y.Y. Wai, Y.L. Chen, Ch.C.H. Chan, Ch. Lin \& T.M.C. LEE (2018) 'The Relationships between Brain Structural Changes and Perceived Loneliness in Older Adults Suffering from Late-Life Depression', International Journal of Geriatric Psychiatry 33, 606-12 (http://doi.org/10.1002/gps.4831).

Singh, A. \& N. Misra (2009) 'Loneliness, Depression and Sociability in Old Age', Industrial Psychiatry Journal 18, 51-55 (http://doi.org/10.4103/0972-6748.57861). 
SzÉMAN, Zs. (2012) 'Skype az idősgondozásban: egy intervenciós kutatás tapasztalatai’ [Skype in Elderly Care: Experiences of an Intervention Study] Esély 2012/2, 38-53.

UTASI, Á. (2002) 'A társadalmi integráció és szolidaritás alapjai: a bizalmas kapcsolatok' [The Foundations of Social Integration and Solidarity: Confidential Relationships] Századvég 7:24, 3-25.

VAJDA, K. (2017) ‘Az Active Ageing és az idősellátás jövőbeni lehetőségei: Innovációk, jógyakorlatok, kutatások' [Overview of Active Ageing and the Future Opportunities of Elderly Care: Innovations, Good Practices, Researches] Esély 2017/6, 77-91.

Van Eenoo, L., A. DeclercQ, G. Onder, H. Finne-Soveri, V. Garms-Homolová, P.V. Jónsson, O.H.M. Dix, J.H. Smit, H.P.J. van Hout \& H. G. van DER Roest (2016) 'Substantial Between-Country Differences in Organising Community Care for Older People in Europe: a Review', European Journal of Public Health 26, 213-19 (http://doi.org/10.1093/ eurpub/ckv152).

VArGHA, L. (2017) 'Hogyan mérjük a társadalmi öregedést?' [How to Measure Ageing of the Society?] in Ezüstkor: korosodás és társadalom: Konferencia kötet (Budapest: Központi Statisztikai Hivatal) 5.

Walker, A. \& T. Maltby (2012) 'Active Ageing: A Strategic Policy Solution to Demographic Ageing in the European Union', International Journal of Social Welfare 21, 5117-30 (https://doi.org/10.1111/j.1468-2397.2012.00871.x).

Wong, A., A.K.C. ChaU, Y. FAnG \& J. Woo (2017) 'Illuminating the Psychological Experience of Elderly Loneliness from a Societal Perspective: a Qualitative Study of Alienation between Older People and Society', International Journal of Environmental Research and Public Health 14, 824 (http://doi.org/10.3390/ijerph14070824).

Zaidi, A., K. Gasior, M. Hofmarcher-Holzhacker, O. Lelkes, E. Zólyomi, B. Marin, R. Rodrigues, A. Schmidt \& P. Vanhuyssen (2013) Active Ageing Index 2012, Concept, Methodology and Final Results, retrieved 26 Nov 2018 from https://www.researchgate.net/ publication/256008735_Project_Active_Ageing_Index_AAI'AActive_Ageing_Index_2012 Concept_Methodology_and_Final_Results.

Zaidi, A., S. HARPer, K. Howse, G. Lamúra \& J. Perek-Bialas, eds. (2018) Building Evidence for Active Ageing Policies 2018-Active Ageing Index and its Potential (Singapore: Palgrave Macmillan).

Zhong, B.L., S.L. Chen, X. Tu \& Y. Conwell (2017) 'Loneliness and Cognitive Function in Older Adults: Findings from the Chinese Longitudinal Healthy Longevity Survey', The Journals of Gerontology: Series B 72, 120-28 (http://doi.org/10.1093/geronb/gbw037).

ZsARNócZKY, M. (2016) The New Hope for the EU - Silver Economy, conference paper, retrieved 12 Feb 2019 from http://matraresorts.com/publications/the-new-hope-for-the-eu-silver-economy-martin-zsarnocky.pdf.

United Nations (2017) Ageing, retrieved 20 Jan 2019 from http://www.un.org/en/sections/issuesdepth/ageing/.

World Health Organization (2014) Active Ageing: a policy framework, retrieved 20 Jan 2019 from http://apps.who.int/iris/bitstream/10665/67215/1/WHO_NMH_NPH_02.8.pdf.

World Health Organization (2017) 10 Facts on Ageing and $\bar{H}$ ealth, retrieved 20 Jan 2019 from https://www.who.int/features/factfiles/ageing/en/.

World Health Organization (2018) Ageing and Health: Key Facts, retrieved 7 Dec 2018 from https://www.who.int/news-room/fact-sheets/detail/ageing-and-health. 